\title{
Language Shift and Language Maintenance in Indonesia
}

\author{
Simon Musgrave \\ Monash University
}

\begin{abstract}
Indonesia is a large nation in terms of both geography and population, and a very large number of languages are spoken within its territory. Historically, multilingualism was and is the norm in many parts of the archipelago, and common even in areas where one language dominates. The emergence of a unitary state with a national language after World War 2 has exerted pressure towards greater uniformity, but the shifts which are taking place are best viewed as changing patterns of multilingualism, rather than as shifts of large populations from one language to another. Such shifts in patterns of language use are occurring throughout the nation, and are resulting in threats to the viability of some languages, especially in the eastern part of the archipelago where there are many languages with small speaker populations. The size of the language groups in the east also has consequences for language maintenance. Although official policy recognises the right of different language groups to maintain their languages and cultures, resources for such activities are scarce and the large ethnolinguistic communities in the west, where several languages have speaker numbers in the millions, have been more successful in accessing resources and institutional support which assist language maintenance. In contrast, speaker groups in the eastern part of Indonesia have limited access to resources available for language maintenance, although recent funding initiatives by organisations based in Europe have at least assisted in drawing attention to the problems faced in that region.
\end{abstract}

\section{Introduction ${ }^{1}$}

The Republic of Indonesia is a very large nation with a correspondingly large population and great linguistic diversity. The nation extends over almost 3,000 kilometres: from Banda Aceh at the western tip of Sumatera to Kupang in West Papua is approximately 2,830 kilometres. Estimates vary, but the nation includes somewhere in the region of 17,000 islands of which 6,000 are inhabited. This makes Indonesia the $14^{\text {th }}$ largest nation on earth by land area. According to the national census of 2000, the population then was 206,264,595 (Statistics Indonesia, accessed 24/08/08), making Indonesia the fourth largest nation on earth by population. Ethnologue 15 (Gordon 2005) lists Indonesia as having 742 languages spoken within its borders, although other sources suggest that the methodology adopted in this publication results in a figure which is too high (Steinhauer 1994). On the basis of their figure, Ethnologue makes Indonesia the $26^{\text {th }}$ most linguistically diverse nation in the world.

The Republic of Indonesia has as its national language Bahasa Indonesia ('language of Indonesia'), which is a standardised Malay variety. The period since the founding of

\footnotetext{
${ }^{1}$ I am grateful to Michael Ewing, Yacinta Kurniasih and Howard Manns for discussion and comments which assisted me in preparing this chapter, and to Aline Scott-Maxwell of the Asian Studies Research Library, Monash University, for bibliographic assistance.
} 
the Indonesian nation, since 1945, has coincided with great changes in communications and technology, and it is not surprising that knowledge and use of the national language has increased over this period. While this has led to some linguistic homogenisation and the process is continuing, I will suggest that this has not led to a reduction in the richness of linguistic repertoires of individual speakers. At the individual level, there have been processes of language shift, but such shifts have taken place within existing patterns of multilingualism (within which I include use of multiple registers of a single language).

There is a very significant linguistic divide between the western part of Indonesia and the eastern part of the nation. As far east as Sumbawa, there are a number of languages with large speaker numbers, and all of the languages are from the Austronesian family. East of Sumbawa, most languages have only small speaker populations and some non-Austronesian languages appear. These languages are the majority in West Papua, but they also are present in, for example, North Halmahera and in the Timor-Alor-Pantar region. Historical evidence suggests that as recently as the early nineteenth century a non-Austronesian language may have been spoken as far west as Sumbawa (Donohue 2007). This linguistic divide naturally has consequences for sociolinguistic change. I will suggest in this chapter that processes of language shift are quite similar in both parts of Indonesia, but that the small size of ethnolinguistic groups in the eastern part of the nation means that language maintenance is much less likely to occur or to succeed in the east.

In the following section, I present a very brief summary of the linguistic history of the Indonesian archipelago. I will then present some quantitative evidence regarding trends in language use over the last forty years, followed by a more qualitative analysis of the current situation in two areas: Java in the west and Central Maluku in the east. In the final section of the chapter, I summarise the main points of the discussion and speculate about the future prospects for the linguistic situation in Indonesia.

\section{Historical Perspective}

The Austronesian expansion had included the Indonesian archipelago as far as the borders of Melanesia by approximately $1500 \mathrm{BC}$, that is, 3,500 years before the present (Bellwood 1995). Archaeological evidence makes it clear that the region was inhabited prior to the arrival of the Austronesian people, and the general assumption is that those inhabitants spoke languages related to the non-Austronesian ('Papuan') languages of New Guinea. The existing inhabitants were supplanted to the extent that only very limited linguistic traces of them remained: possibly the extinct language of Tambora (Donohue 2007), and certainly the languages of North Halmahera and Timor-Alor-Pantar. The Austronesian presence never extended far from the coast on New Guinea, and even there it is quite limited. The non-Austronesian languages of West Papua can therefore be taken as representative of a continuous heritage from pre-Austronesian times. There is debate as to whether the non-Austronesian languages of Halmahera and Timor-Alor-Pantar represent a similar continuous presence or whether they are the result of later migration of Papuan people into Austronesian areas (see Wurm 1975 for discussion of the Timor-Alor-Pantar situation, Platenkamp 1990, Voorhoeve 1994 and Bellwood 1998 for Halmahera, and McWilliam 2007 for recent anthropological arguments). 
The linguistic situation which existed by the time of European contact with the region at the start of the sixteenth century had been shaped by two closely related factors: the types of political organisation which had arisen, and by previous trading activity.

Large polities, recognised and mentioned as such by outsiders, came into existence in Sumatera and Java (Brown 2003: 11-28). As far as is known, these polities were not tightly organised; nevertheless the relative linguistic uniformity in these areas surely owes something to the existence of such groupings. In contrast, eastern Indonesia lacked larger political groupings, and, when they did exist, they were even less tightly organised. For example, the sultanate of Tidore (an island just to the west of Halmahera) exerted control as far south as Ambon and Buru Islands at times (Andaya 1993), but its non-Austronesian language did not spread. The second major factor, trade, was closely linked to the first. The spices native to the archipelago, especially cinnamon and cloves, were highly desirable trade goods and there is evidence that they were traded as far as the Middle East before the start of the Common Era. Trade with China and India became important in the first millennium (Brown 2003: 13-17, Wolters 1967), and the new polities in the Indonesian archipelago were partly motivated by the desire to control trade routes and ports. Trade which extended throughout the archipelago required a lingua franca. The Straits of Malacca, the narrow passage between Sumatera and peninsular Malaysia, was a key point in the trade system, and Malay, the language spoken there, came to be accepted as a language of wider communication (Sneddon 2003a: 35ff). In some areas, so-called Bazaar Malay was used only for inter-ethnic communication, but in other areas its use spread to other domains and finally resulted in creole and post-creole varieties, as in Ambon (Grimes 1991) and Manado (Prentice 1994).

European control of the region came in the sixteenth century. Portuguese ships reached Malacca in 1511 and Maluku in 1512 (Brown 2003: 33). A Portuguese-based creole was widely used in ports across the region thereafter and its use persisted after the Portuguese yielded control to the Dutch early in the seventeenth century (Sneddon 2003a: 79-80). These new European arrivals quickly realised the importance of Malay as a common language across the region. Even in areas where a single language was used across a large area, such as Java, the Dutch preferred to use Malay as the interlanguage between colonisers and colonised, and Dutch was used very little. The Protestant missionaries who accompanied Dutch rule chose to use Malay as the language of religious instruction, and this choice had important effects. ${ }^{2}$ A division between so-called Low Malay (or Bazaar Malay) and High Malay was entrenched, and the adoption of High Malay for religious teaching motivated moves towards a standardisation of that variety (Sneddon 2003a: 84-85).

When nationalist movements began in Indonesia early in the twentieth century, the question of language was a difficult one. It was considered essential that a unitary state of Indonesia should have a single national language, but which language to choose was not immediately obvious. Javanese was the language with the greatest number of native speakers, but it was scarcely spoken outside of Java, and not even universal across that island. In addition, choosing Javanese as the national language

\footnotetext{
${ }^{2}$ Islam had spread across the archipelago several centuries earlier and with it, some knowledge of Arabic. The language, however, was and is restricted to one domain of use and has had little impact on the language situation aside from a large number of loan words which occur in Indonesian (and in many other languages also).
} 
would carry a message of Javanese dominance in the new political structure, at a time when national unity was being sought. The only viable alternative was seen to be Malay, which was already known widely in the region (in one form or another), and which had already succeeded as a language of administration under the Dutch. Therefore the Second Indonesian Youth Conference of 1928 adopted a resolution which included the following clause: ${ }^{3}$

\section{Kami putera dan puteri Indonesia menjunjung bahasa persatuan, Bahasa Indonesia. \\ We, the sons and daughters of Indonesia, uphold the language of unity, the language of Indonesia.}

The language was given a new name, but it was not a new language: it was the High Malay which already existed (Sneddon 2003a: 102). The Republic of Indonesia declared independence in 1945, but it was 1949 before the status of the new nation was fully recognized. Since then, Bahasa Indonesia has been the national language, the language of administration and education, and the language of the national media. What speakers mean by the term bahasa Indonesia is, however, not straightforward. There is an approved national standard set out in Alwi et al (1998), but this variety is used only in the most formal contexts. Sneddon (2003b) has argued that a diglossic situation exists, with the formal standard having the status of the high code and a colloquial variety, or perhaps more accurately, a range of colloquial varieties, having low status (see also Ewing 2005). While the constitution of the Republic of Indonesia accords Bahasa Indonesia the status of national and official language, it also guarantees the preservation of "those vernaculars which are properly maintained by their speaker” (Explication of Chapter XV, Article 36, as cited by Nababan 1985).

This brief account of the linguistic history of Indonesia has, I hope, made it clear that some degree of multilingualism has long been the norm in the region. Any area which had trading contacts beyond the most local would have been exposed to Bazaar or Low Malay (and possibly other lingue franche) and any area which experienced interaction with the Dutch colonial authorities would have had contact with some variety of Malay and very likely both High and Low varieties. In addition, areas of higher linguistic diversity, especially in the eastern part of the nation, always had a greater need for interethnic communication and the concomitant linguistic accommodations. Included in this array of elements which might be included in an individual's linguistic repertoire, if that individual came from the area including Java, Bali and Lombok, was knowledge of a complex speech level system, enlarging linguistic repertoires still further (for Javanese, see Wolff and Poedjosoedarmo 1982, for Balinese, Clynes 1995, for Sasak [Lombok] see Nothofer 2000).

Another factor which has complicated the language situation in Indonesia since independence has been the government's policy of encouraging internal migration or transmigrasi (see Rigg 1991: 80-108). The results of this policy can be seen in data extracted from the 1990 national census, which shows that Javanese was spoken by more than $10 \%$ of the population in eight provinces outside the island of Java on Sumatera and Kalimantan (Steinhauer 1994, Table 6). Although Javanese were the

3 It is interesting to note that some speakers at this conference used Dutch (Sneddon 2003:

101). 
ethnic group most affected by transmigrasi, substantial numbers of speakers of other languages, for example Buginese, have also been spread across the nation. The increased necessity for inter-ethnic communication which results can be considered as another historical factor which has contributed to processes of language shift which can be seen today.

\section{The impact of the national language - quantitative data}

Various questions about language use were asked in the Indonesian censuses made in 1971, 1980 and 1990. No such questions were included in the 2000 census and it is therefore not possible to analyse trends beyond 1990. A careful analysis of the data over the three censuses just mentioned was carried out by Steinhauer (1994), and that work is the source of data for the figures to be presented below. ${ }^{4}$

Two aspects of the data are of interest in the present context: the extent of the adoption of Bahasa Indonesia amongst the population, and the number of first language speakers of various languages. There are problems in interpreting both of these types of data. In the first case, the census asked slightly different questions of the respondents on each occasion. The major problem, however, is in knowing what value to give to the responses of those who did claim to speak Indonesian. It is likely that respondents felt some pressure to exaggerate their abilities, as using the national language could be viewed as a mark of good citizenship. In addition, it is not clear whether census takers or respondents distinguished between knowledge of Bahasa Indonesia, the standardised national language, and knowledge of other Malay varieties. For example, would a speaker of Manado Malay (but not of Bahasa Indonesia) answer 'Yes' to the census question? As Steinhauer (1994) comments, we can only assume that these factors did not change significantly over the period in question. ${ }^{5}$ For the second type of data, the interpretative problem is due to the way that the results were reported by the Badan Pusat Statistik (the Central Statistical Agency, now known as Statistics Indonesia). For the question about knowledge of a regional language, the published results report for only the eight largest languages; all others are grouped together as 'others'. The results allow us to see some overall trends in the use of these regional languages, but we can only guess at the trends which might show up in the case of the many smaller languages.

Figure 1 shows the absolute number of speakers of Indonesian reported for the three censuses, divided into three age groups.

\footnotetext{
$4 \quad$ More detailed analysis of the data from the 1980 census is presented in Masinambow and Haenen (2002), but the absence of trend data makes the discussion presented there less useful for present purposes.

5 The issues concerning how speakers understand the extension of the language name mentioned previously are of course also relevant.
} 


\section{Figure 1}

\section{Number of people claiming knowledge of Bahasa Indonesia}

1971 - 1990 (No data was collected for children under 5 in 1990)

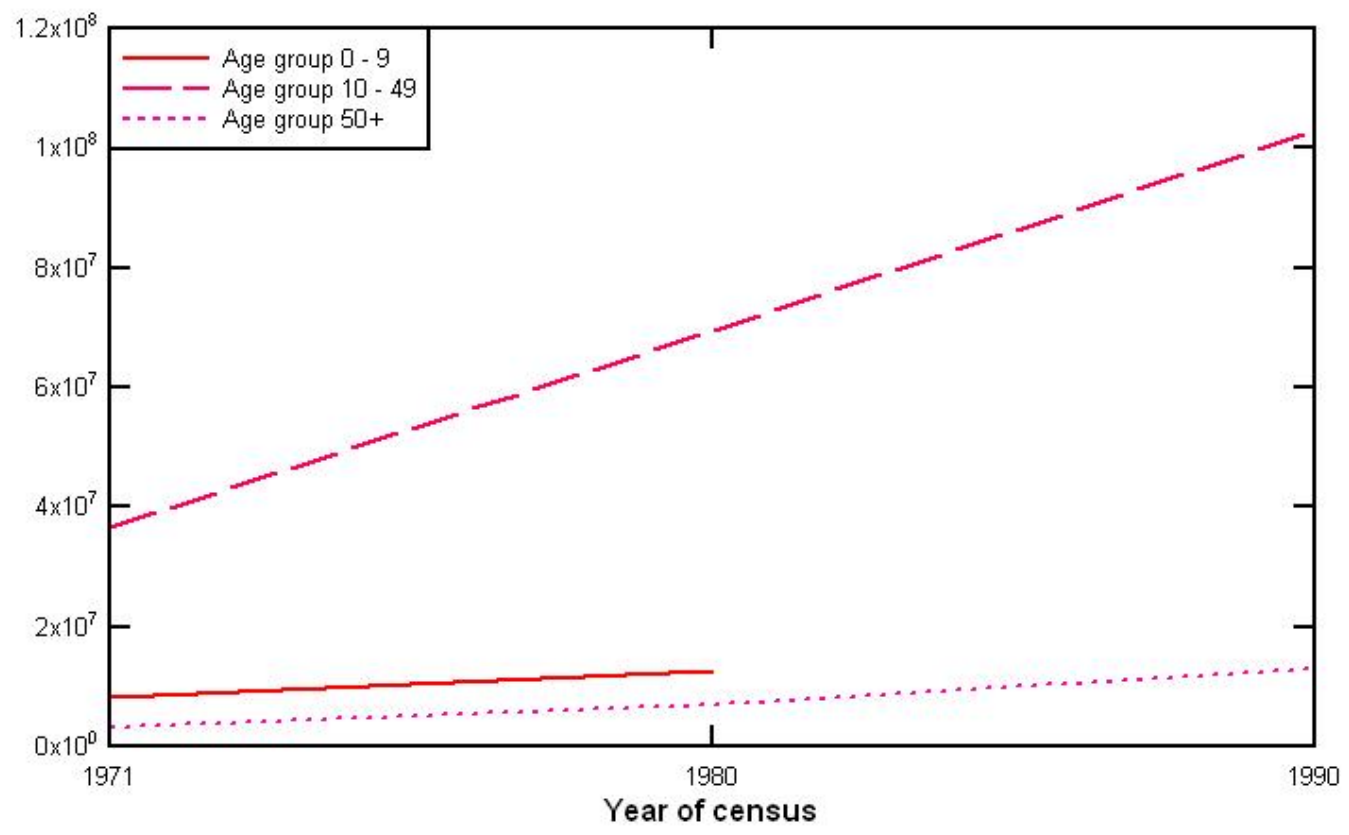

It is clear that the number of speakers increased over the 19 year period in all age groups, but especially in the 10 - 49-year-old age bracket. However, the overall population of the nation also increased over the same period, so it is useful to also consider Figure 2, which shows the percentage of the population who claimed to be speakers of Indonesian.

\section{Figure 2}

\section{Percentage of population claiming knowledge of Bahasa Indonesia} 1971 - 1990 (No data collected for children under 5 in 1990)

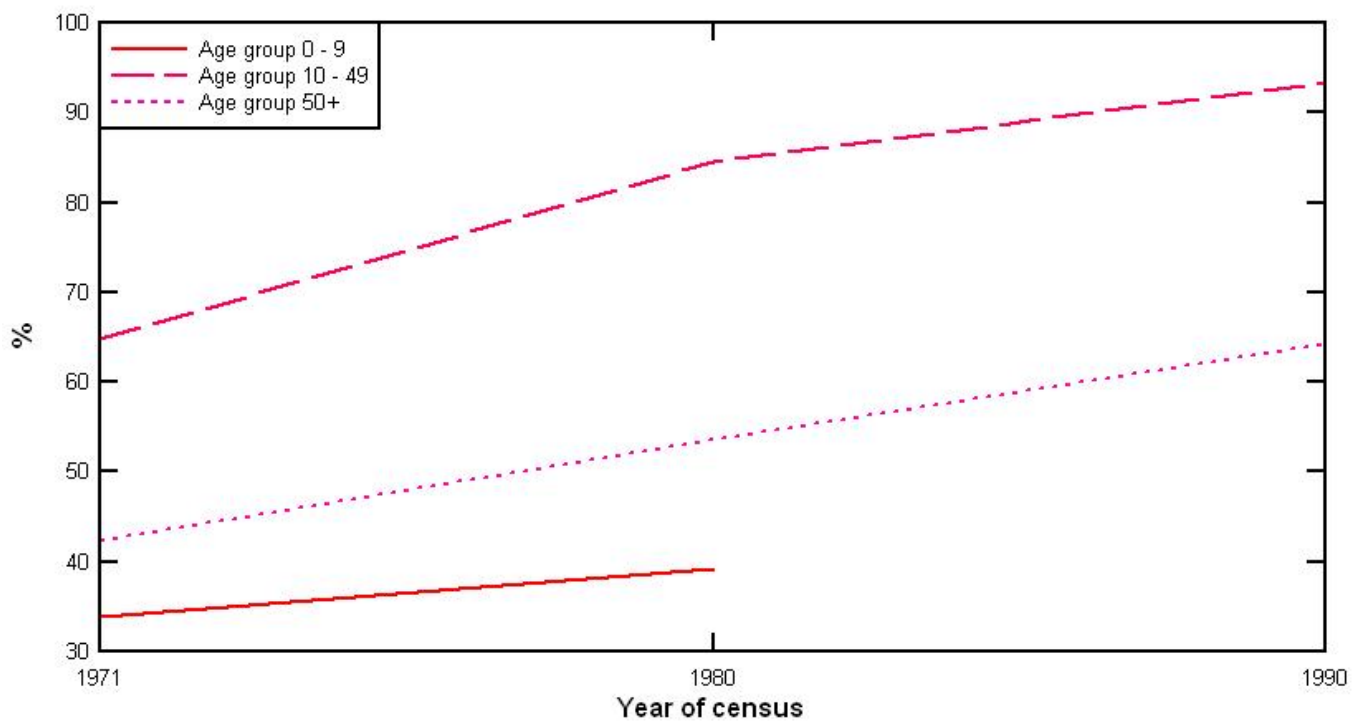


This figure, unlike Figure 1, shows that the proportion of people with knowledge of Bahasa Indonesia was lowest in the youngest age group. This reflects the fact that in many places another language was the home language and exposure to and learning of Indonesian did not start until school. This figure also shows that the rate of increase in the middle age bracket slowed a little between 1980 and 1990. This can probably be attributed to the fact that the percentage was already very high. By 1990, in specific demographic groups, knowledge of Indonesian was approaching 100\%: For urban males aged between 10 and 49, the figure was $98.8 \%$ and for females it was $96.7 \%$.

Figure 3 shows the percentage of the population who were first language speakers of the eight major languages, Indonesian, and the 'other' category comparing 1980 with 1990.

Figure 3

\section{Percentage of first language speakers of major languages 1980 and 1990 censuses}

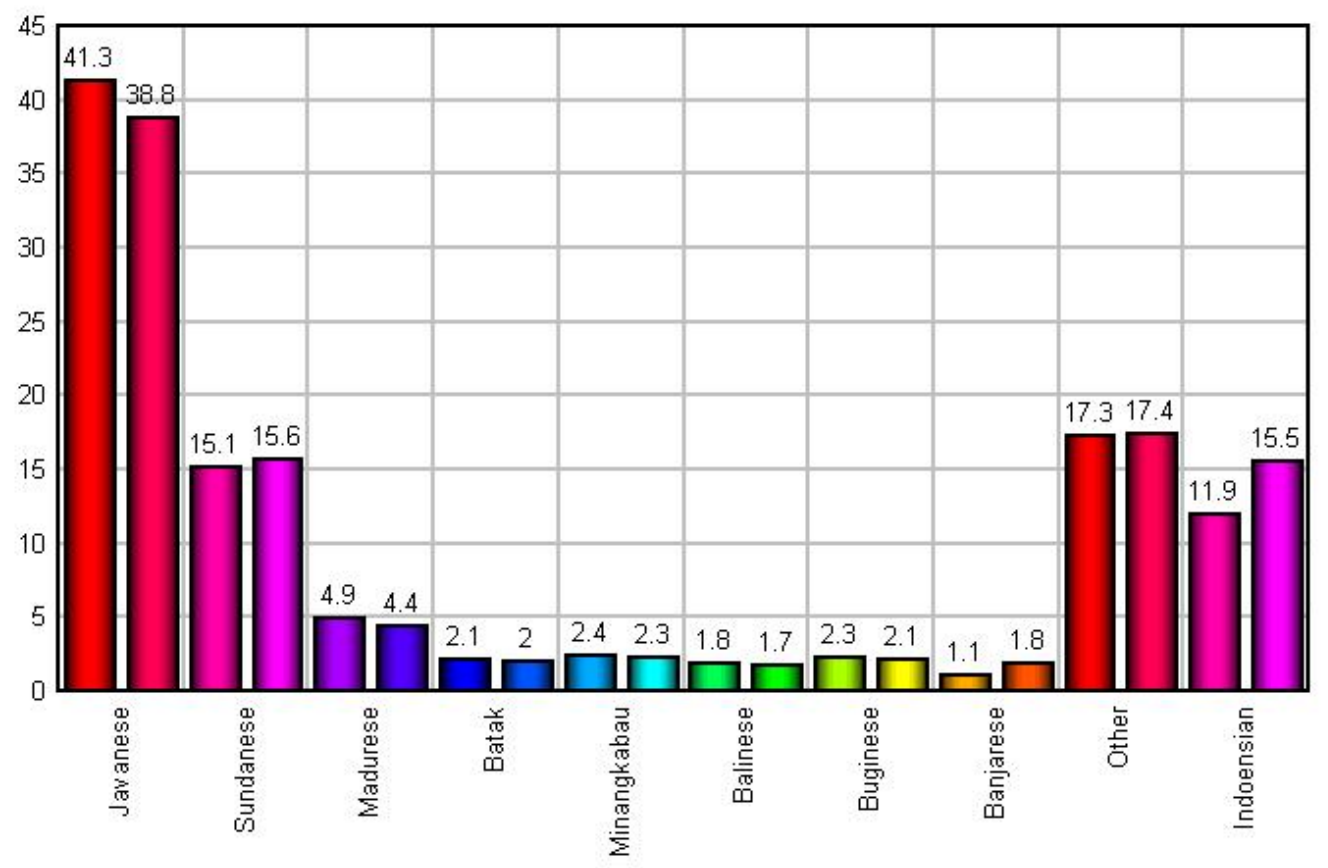

The important points to note here are that only two of the eight major languages increased their percentage of speakers: Sundanese and Banjarese. The 'other' category also shows a small increase, and Indonesian a larger one. In percentage terms, the increases for Sundanese and for the 'other' languages are small: 3.3\% and $0.6 \%$ respectively. On the other hand, the percentage increases for Bahasa Indonesia and Banjarese are much larger at 30.3\% and 63.6\%. This huge increase for Banjarese represents an additional 1.3 million speakers. Steinhauer (1994) suggests that this increase is due to a rapid decline in the use of many smaller local languages in South and Central Kalimantan and shift by the speakers to the local language of wider communication, Banjarese, rather than to the national language. If this interpretation is correct, we would expect that a similar shift might be happening in many areas in eastern Indonesia; such a shift not being visible in the statistics because the local languages of wider communication are too small to be separately reported in the 
statistics. The discussion of the language situation in Central Maluku in the following section will confirm this prediction. ${ }^{6}$

[insert Figure 4 about here]

Figure 4 compares the overall change in the proportion of first language speakers for each group with the change in the youngest age group represented in both censuses, 5 -9 years of age. In this figure, we can see evidence that transmission of regional languages to the youngest generation was declining over the decade in question. Of the language groups which showed an increased proportion of first language speakers, only 'other' and Indonesian showed a greater increase in the youngest group than in the overall population, and as already noted, the figure for 'other' must be viewed with caution. On the other hand, all of the groups which showed an overall decline in percentage had a greater percentage decline in the youngest group, with the exception of Batak, where the two figures are almost the same. Even Banjarese, the one regional group with a very large increase in its overall proportion, showed a rather lower rate of change in the youngest group. This data therefore shows that Bahasa Indonesia was the only language which both increased its proportion of first language speakers in the overall population and in the youngest age group, suggesting a significant overall shift of speakers to that language.

\section{The impact of the national language - qualitative accounts}

The statistical data just presented give some insight into processes of language shift resulting from the impact of the national language in Indonesia, but this picture needs to be supplemented with more detailed examinations of the situation of individual languages and their speakers. This is particularly true for small languages from eastern Indonesia, which disappear into an amorphous 'other' category in the statistics, and I will discuss the situation in Central Maluku in section 4.2. But it is also useful to consider in a qualitative way what is happening to large language groups, and in section 4.1 I will therefore briefly report some current research on the situation of Javanese. While certain commonalities can be seen across these two situations, the great differences between the sociolinguistic situation in the western and eastern parts of Indonesia mean that the local effects of language shift are rather different in the two locations and that the possibilities for language maintenance are very different.

\subsection{Java}

Of the eight languages for which individual speaker numbers are provided in the census data, three are spoken on the island of Java: Javanese, Sundanese and Madurese. In this section, I present information from recent and ongoing research on the current status of the Javanese language in three different locations and in different social settings. One researcher (Kurniasih 2006) examines the linguistic repertoires of

$6 \quad$ Steinhauer suggests two additional reasons why the 'others' category should be treated cautiously. Many of these languages are spoken in the most remote areas of the nation and therefore they are likely to be lagging in any shift to the national language, and there may be classification problems in data. 
school age children and their parents in Yogyakarta (Central Java), considered the centre of Javanese culture. Goebel (2003) analyses code choices in spontaneous interactions recorded in Semarang (Central Java), and Manns (2007, work in progress) is studying the construction of identity through language choices amongst young people in Malang (East Java). In each situation, there is evidence that shift from Javanese to Indonesian is taking place, but there is also evidence which shows that Javanese continues to be used by many speakers and that there is some institutional support for those who wish to maintain the language.

The data examined in the previous section showed that (at least up until 1990) Javanese was the language with the greatest number of first language speakers in Indonesia, but that the percentage of the population who spoke it as their first language was declining. This decline has been noted and discussed in local newspapers, radio and television shows as well as in academic forums (Kurniasih 2006). Prior to 1990, regional languages were used as the medium of instruction in the first three grades of primary school in many places, and this was common in Javanese-speaking areas. Since 1990, it is government policy that Indonesian should be used as the language of education from kindergarten through to university. However, another government policy was promulgated in various forms between 1989 and 1993 which requires the teaching of one compulsory local content subject and up to three optional subjects in the primary education curriculum alongside the national curriculum. This policy has allowed Javanese to reappear in schools, but as a taught subject rather than as the medium of instruction. In the Special Region of Yogyakarta, Javanese has been a compulsory subject in schools from year 1 to year 9 since 1995, allotted two teaching hours per week, and in Central Java it has even become a compulsory subject for students in years $10-12$ of high school since 2006 (Kurniasih 2006). It is of particular interest that the relevant departmental policies explicitly state that both the Low and High forms of the language will be taught (Kurniasih 2006).

Kurniasih's research (Kurniasih 2006) looks at patterns of language use for schoolage children (11 and 14 year olds) at home and at school, and also the language use of the children's parents when talking to their children and when talking to their social networks. The strongest trend emerging from this research is that middle class parents and children are much more likely to use Indonesian than their working class counterparts. An additional finding is that mothers and female children are more likely to use Indonesian than their male counterparts. Very strikingly, only middle class children were observed to use only Indonesian with no Javanese at all, and five times more girls than boys showed this behaviour. Kurniasih's data also suggests that this is to some extent a conscious choice being made by parents: in interacting with their social networks, no parents used Indonesian alone, but in speaking to their children, $88 \%$ of middle class mothers and $39 \%$ of middle class fathers used no Javanese (no working class parents behaved in this way). The data also suggests that the High variety of Javanese, kromo, is less likely to be a part of the linguistic repertoire of middle class children. While the language use patterns of working class children typically include kromo, whether or not some Indonesian is included also, the middle class children's usage tends towards either Low Javanese, ngoko, with Indonesian, or Indonesian alone. Again, the data suggest that choices by parents may be influencing the children's usage patterns: in their social networks, the middle class 
parents incorporate kromo (95\% for mothers and 98\% for fathers), but in speaking to their children, these figures drop enormously (to 8\% and 37\% respectively).

Some of the findings of Kurnisaih (2006) have correspondences in Goebel's research on code choice in urban neighbourhoods of Semarang on the north coast of Central Java (Goebel 2005). Goebel examines interactions between males and Javanese is used frequently, in line with Kurniasih's findings that males are more likely to use Javanese than females across all social classes. Goebel reports the use of both ngoko and kromo Javanese in various settings, but found that symmetrical exchanges were the norm rather than the asymmetrical exchanges reported by previous researchers (for example Wolff and Poedjosoedarmo 1982). His interpretation of the data is that ngoko is used to index familiarity, while kromo and also Indonesian are used to index a greater social distance between the interactants. Goebel also observed the use of ngoko Javanese by ethnic non-Javanese in familiar settings, going against the normal opinion that Indonesian is the language of inter-ethnic communication. The data come from two neighbourhoods in Semarang with different socioeconomic profiles, and Goebel also notes that the neighbourhood which is more working class in character affords greater opportunities for interaction and therefore a higher level of familiarity is the norm. His results therefore complement those of Kurniasih, and throw additional light on those earlier results. Both kromo Javanese and Indonesian can be used for certain functions, those associated with communication with less familiar interactants ${ }^{7}$, and there is some sign of blurring as to the function of the two languages in such situations. This process is more likely to be associated with middle class speakers than with working class speakers (cf. Syahdan 2000, on the use of Indonesian by educated Sasaks).

Goebel's data show that Javanese retains great vitality in many contexts. That this is the case even in the language use of young people is also shown by data from Malang in East Java (Manns 2007, personal communication). The research in question is examining the impact of the Jakarta variety of Indonesian on the language used by young adults in an urban environment. Many of the speakers studied in this research are university students who aspire to modernity - they are often technologically literate and they aim for careers in areas such as economics. Even in this environment, however, Javanese still has a place and is used for various purposes such as establishing an identity as Javanese (rather than Indonesian). Javanese is used as a language of familiarity in some contexts, as in Goebel's study, but in line with Kurniaish's findings, such use is almost always of ngoko. Javanese can be used even in a situation where the means of communication itself might be expected to exert pressure towards language use which would be seen as modern. Thus, Javanese can turn up in bahasa chat, the variety used in online messaging (Manns 2007).

The various studies discussed here suggest that the proportion of the population of Java who acquire and use Javanese is declining. There is a language shift to Indonesian taking place and this process is being led by middle class females. Against this, the data also shows that the language is maintaining its hold on some domains of use and retains vitality amongst at least some social groups. It also seems likely that the first major impact of this process of language shift, if it continues, will be seen in

\footnotetext{
${ }^{7}$ Manns (personal communication) reports that, at least to some degree, young people in Malang still use kromo or, alternatively Indonesian, to index respect for age and status, even among familiars.
} 
the system of speech levels. High Javanese, kromo, appears to be the most vulnerable part of the language. There is awareness in the Javanese community that language shift is happening, and ways of acting to assist language maintenance have been found within the institutions of the nation.

\subsection{Central Maluku}

The linguistic situation in the Maluku region of eastern Indonesia is very different to that in Java. Aside from the difference in the size of the speaker populations of languages, the unique history of the region led to a process of language shift away from indigenous local languages which happened comparatively early in at least some communities. The communities which retained their languages are now generally following the same trajectory, and prospects for language maintenance in such communities are very poor. In this section, I concentrate on data from the Central Maluku region and also on the relationship between religious affiliation and language shift.

Central Maluku in eastern Indonesia has a distinctive linguistic ecology. Firstly, the region has high linguistic diversity with forty two languages from the Austronesian language family on fourteen islands. Secondly, several indigenous languages have already vanished in this region and it remains the area with the highest degree of language endangerment in Indonesia (Florey 2005). Finally, while the population of Indonesia is predominantly Muslim, Central Maluku has the highest proportion of Christian inhabitants of any province of the nation.

The common language of the region is Ambonese Malay, a variety of Malay influenced by Portuguese, Dutch and indigenous languages (Grimes 1991, van Minde 1997). Central Maluku was a crucial link in the trading routes for spices and has been subject to extensive influence from outside forces for a long period. The shift from indigenous languages to Malay therefore began comparatively early in this region and has historically been linked to Christianity. Each village outside of Ambon city is identifiable as either Christian or Muslim and the fate of indigenous languages has been different in different villages according to religious affiliation. The observations of Wallace on his visit to Ambon in 1857 suggest that this linguistic differentiation was already evident by that date (Wallace 1869:230-231). Twenty five years ago, Collins commented: "Today the surviving descendants of Proto-East Piru Bay languages are spoken generally only in Muslim villages or only by a handful of the oldest speakers in a few Christian villages.” (1983:99).

More recent research, however, suggests that the dichotomy between Christian and Muslim communities in Maluku is not as clear-cut as has generally been thought (Musgrave and Ewing 2006). The research reported in that study included testing of linguistic vitality at various locations on Ambon Island and on Seram Island. That testing showed that the community where the local language was maintained most successfully was a Christian community in the mountains of Seram, Lohiasapalewa, where Alune is spoken. ${ }^{8}$ Physical isolation and a strong local identity contributed to this situation. And while it was true that, in general, local languages had been

\footnotetext{
${ }^{8}$ These particular results are not reported in Musgrave and Ewing 2006, which concentrates on the communities of Allang and Tulehu on Ambon Island. Details can be found in Florey 2006.
} 
maintained longer in Muslim communities, language shift is now happening very fast in those communities. Table 1 shows the results for a lexical recognition test recorded in Tulehu village on Ambon Island where the local language is known as Bahasa Tulehu or Sou Amana Teru ('language of the three villages').

\begin{tabular}{|lclc|}
\hline Age Group & Males & Females & Overall \\
\hline SD-4 & $27(51 \%)$ & $27(51 \%)$ & $27(51 \%)$ \\
\hline SMP-2 & $44(83 \%)$ & $47(89 \%)$ & $46(87 \%)$ \\
\hline SMA-2 & $39(74 \%)$ & $44(83 \%)$ & $42(79 \%)$ \\
\hline $\mathbf{1 8}-\mathbf{3 0}$ & $50(94 \%)$ & $51(96 \%)$ & $50(94 \%)$ \\
\hline $\mathbf{3 0}-\mathbf{5 0}$ & $50(94 \%)$ & $51(96 \%)$ & $51(96 \%)$ \\
\hline $\mathbf{5 0 +}$ & $52(98 \%)$ & $51(96 \%)$ & $52(98 \%)$ \\
\hline
\end{tabular}

Table 1 - Mean scores for a 53 item lexical recognition test, Tulehu Note - Mean age given to nearest whole year. SD-4 = Primary School (Sekolah Dasar) grade 4; SMP-2 = Junior High School (Sekolah Menengah Pertama) class 2 (grade 8); SMA-2 = Senior High School (Selolah Menengah Atas) class 2 (grade 11).

Subjects over the age of 18 were able to recognise almost all the vocabulary items in the test, but below that age, performance drops off rapidly. The lexical recognition test was the first stage in a multi-stage testing process and when overall performance was considered, it was clear that only those over the age of 30 could be expected to have good command of the language, with primary school children having little or no knowledge beyond basic vocabulary. Thus, although Sou Amana Teru still has approximately 10,000 fluent speakers, it seems unlikely to survive beyond another two generations.

Most Christian villages in Central Maluku followed a trajectory of language shift which was fully accomplished even before Indonesian independence. This shift was from a situation where a local language was used for intra-community purposes and Ambonese Malay (or some other Malay variety) was used for inter-community purposes, such as trade and dealings with the colonial power, to a situation where Ambonese Malay became the language of daily life and some other version of Malay, closer to High Malay, was used for some purposes. ${ }^{9}$ A similar trajectory is now being followed by the villages, largely Muslim, which had retained their local languages, with the difference that Indonesian is the second Malay variety which is involved.

The educational policy which imposes local content in the primary curriculum (muatan lokal) applies in Maluku as in Java, but its effects are very different. Firstly, as mentioned above, there are forty two languages spoken in the region. Most of these are spoken only in a small group of villages and speaker numbers for any single language are small. The possibility of there being adequate resources available to prepare teaching materials for any language are therefore very small, in contrast to the situation in Java where around 60 million people speak the one language. Secondly,

\footnotetext{
${ }^{9}$ Some highly educated members of the community would have known and used Dutch, and traces of Dutch usage remain in everyday speech in Ambon. This persistence perhaps owes something to ongoing contact with an expatriate community in the Netherlands (Florey and van Engelenhoven 2001).
} 
comparison of the statistics quoted from Kurniasih (2006) with the data from Tulehu make it clear that the home environment in Java is, at least in some cases, more conducive to language transmission than that in Maluku. In Java, at least some parents are using Javanese in the home, but in Central Maluku, use of local languages in the home has all but ceased. It is hard not to be pessimistic about the future of the local languages in this region.

\section{Future prospects}

There can be no doubt that processes of language shift have been taking place and continue to take place in Indonesia. Since the installation of Bahasa Indonesia as the national language in 1945, knowledge of that language has spread throughout the population and it has gained enormously in the proportion of people who use it as either their first language or as a second language. But there is not only one simple process of shift from other languages to the national language. There is also significant shift from smaller regional languages to larger regional languages occurring in at least some areas, as revealed by the census data for Banjarese as well as by the situation in Central Maluku. Even where a shift to Indonesian can be isolated, this in itself is not necessarily a simple process. As argued by Sneddon (2003b), bahasa baku ('standard language') or bahasa yang baik dan benar ('language that is good and correct') is not used by anyone as a medium of daily communication. As seen in Malang, shift to Indonesian can actually mean shift to a range of possible varieties on a continuum between a colloquial variety which is shared by educated speakers across the nation, and many much more specific varieties which are situated both geographically and socially. Some varieties have perhaps higher prestige, such as the Jakarta variety described by Sneddon (2006), but that variety is not viewed positively in all situations. In Malang, Manns reports that radio station program directors in some cases instruct announcers to avoid features seen as characteristic of Jakarta in order not to alienate the intended audience (Howard Manns, personal communication). When this range of possible varieties of Indonesian is considered, we can see that the patterns of language shift in Indonesia are best understood as shifts in patterns of multilingualism. Even before independence, many speakers used more than one language or variety in different domains of use, and this remains true today, even though the varieties involved and the domains in question may be changing.

Language maintenance in Indonesia has a somewhat paradoxical status at present. As suggested in the discussion above, the few large regional languages in the western part of the nation have better prospects for language maintenance than the many small languages in the east, even though the needs of those eastern languages are much more pressing. First language speakers of languages such as Javanese are declining as a proportion of the total population, but this is a slow process and no one would consider these languages as endangered by any accepted measure (see for example Krauss 1992). But these are the languages which are in a position to take advantage of the possibilities offered by the education system and to generate concern from large numbers of speakers, which can be turned into political pressure. Language communities in the east have no such advantages. Such communities are typically very small, they are distant from the political centre of the nation, and they are often in the poorer parts of the nation. It is no surprise therefore that in her survey of endangered Austronesian languages, Florey (2005) identifies eastern Indonesia as an 
area of great concern. ${ }^{10}$ There seems little prospect that the resources necessary for maintaining even a handful of these languages can be found within Indonesia. In recent years, there have been a number of language documentation projects situated in eastern Indonesia funded by organisations in Europe. The Hans Rausing Endangered Languages Project has funded work in Central Maluku, in the Alor-Pantar region, and in Flores (Rongga language), while the DoBeS project has funded work in Sulawesi (Totoli language). Such efforts are of great scientific value but, in terms of language maintenance, their impact is limited. Firstly, these projects have targeted a handful of languages when several hundred are at risk, and secondly, they have, by virtue of the funding model used (Musgrave and Thieberger 2007), the nature of short-term interventions. Only sustained activity on the part of the speakers of a language can be expected to have beneficial effects over a long term (see Fishman 1991), and it is as yet too early to say whether any of the projects mentioned above have led or will lead to such activity.

\footnotetext{
${ }^{10}$ One could also mention the non-Austronesian languages of West Papua, which suffer additionally from being situated in a province which is considered problematic by the central government.
} 


\section{References}

Alwi, Hasan, Soenjono Dardjowidjojo, Hans Lapoliwa and Anton M. Moeliono. 1998. Tata Bahasa Baku Bahasa Indonesia $3^{\text {rd }}$ edition. Jakarta: Balai Pustaka.

Andaya, Leonard Y. 1993.The world of Maluku : eastern Indonesia in the early modern period. Honolulu: University of Hawai i Press.

Bellwood, Peter. 1995. Austronesian Prehistory in Southeast Asia: Homeland, Expansion and Transformation. In Peter Bellwood, James Fox and Darrell Tryon (eds) The Austronesians : historical and comparative perspectives 103118.Canberra: Dept. of Anthropology, Australian National University. - 1998. 'The archaeology of Papuan and Austronesian prehistory in the Northern Moluccas, eastern Indonesia.’ In Roger Blench and Matthew Spriggs (eds) Archaeology and Language II: Correlating archaeological and linguistic hypotheses, 128-140. London/New York: Routledge.

Brown, Colin. 2003. A Short History of Indonesia: The Unlikely Nation Crows Nest NSW: Allen \& Unwin.

Clynes, Adrian. 1995. Topics in the phonology and morphosyntax of Balinese : based on the dialect of Singaraja, North Bali. Unpublished PhD thesis, Australian National University, Canberra.

Collins, James T. 1983. The Historical Relationships of the Languages of Central Maluku, Indonesia. Canberra: Pacific Linguistics (D-47)

Donohue, Mark. 2007. The Papuan Language of Tambora. Oceanic Linguistics 46:520-537.

Ewing, Michael C. 2005. 'Colloquial Indonesian'. In Alexander Adelaar and Nikolaus P. Himmelmann (eds) The Austronesian Languages of Asia and Madagascar. London/New York: Routledge.

Fishman, Joshua. 1991. Reversing Language Shift Clevedon: Multilingual Matters.

Florey, Margaret. 2005. 'Language shift and endangerment'. In Alexander Adelaar and Nikolaus P. Himmelmann (eds.) The Austronesian Languages of Asia and Madagascar: pp43-64. London/New York: Routledge.

- 2006. Assessing the Vitality of Endangered Languages in Central Maluku. Paper presented at the $10^{\text {th }}$ International Conference on Austronesian Languages, Palawan, Philippines, 17-20 January 2006.

Florey, Margaret and Aone van Engelenhoven 2001 Language documentation and maintenance programs for Moluccan languages in the Netherlands. International Journal of the Sociology of Language 151: 195-219.

Goebel, Zane. 2005. An Ethnographic Study of Code Choice in Two Neighbourhoods of Indonesia. Australian Journal of Linguistics 25: 85-107.

Gordon, Raymond G., Jr. (ed.), 2005. Ethnologue: Languages of the World, Fifteenth edition. Dallas, Tex.: SIL International. Online version: http://www.ethnologue.com/.

Grimes, Barbara Dix. 1991. The development and use of Ambonese Malay. In Hein Steinhauer (ed) Papers in Austronesian Linguistics No. 1 Canberra: Pacific Linguistics (A-81), pp83-123.

Krauss, Michael. 1992. The world's languages in crisis. Language 68:4-10.

Kurniasih, Yacinta. 2006. Gender, Class and Language Preference: A case study in Yogyakarta. In Keith Allan (ed), Selected papers from the 2005 Conference of the Australian Linguistic Society. http://www.als.asn.au.

Manns, Howard. 2007. Bahasa chat: Colloquial Indonesian in Internet communication. Paper presented at the $4^{\text {th }}$ International Seminar on 
Austronesian Language and Literature, Denpasar, Indonesia, August 2007..

Masinambow, E.K.M. and P.H.W. Haenen (eds). 2002. Bahasa Indonesia dan bahasa daerah. Jakarta: Yayasan Obor Indonesia.

Minde, Donald van. 1997. Malayu Ambong: Phonology, Morphology, Syntax. Leiden: Research School CNWS: School of Asian, African, and Amerindian Studies.

Musgrave, Simon and Michael C. Ewing. 2006. Language and religion: a case study of two Ambonese communities. International Journal of the Sociology of Language 179:179-194.

Musgrave, Simon and Nick Thieberger. 2007. Who pays the piper? In Maya Khemlani David, Nicholas Ostler and Caesar Dealwis (eds) Proceedings of FEL $X I$ - Working Together for Endangered Langauges: Research Challenges and Social Impacts, 47-55. Bath: Foundation for Endangered Languages.

Nababan, P.W.J.1985. Bilingualism in Indonesia: ethnic langauge maintenance and the spread of the national language. Southeast Asian journal of Social Science 13:1-18.

Nothofer, Bernd. 2000. A preliminary analysis of the history of Sasak language levels. In Working Papers in Sasak, Vol. 2, ed. Peter K. Austin, 57-84. Melbourne: University of Melbourne.

Platenkamp, Jos. 1990. North Halmahera: non-Austronesian languages, Austronesian cultures. Leiden: Oosters Genootschap in Nederland.

Prentice, Jack. 1994. 'Manado Malay: Product and agent of language change'. In Tom Dutton and Darrell Tryon (eds) Language Conatct and Language Change in the Austronesian World, 411-442. Berlin/New York: Mouton de Gruyter.

Rigg, Jonathan. 1991. Southeast Asia: a region in transition: a thematic human geography of the ASEAN region. London: Unwin Hyman.

Sneddon, James. 2003a. The Indonesian Language: Its history and role in modern society. Sydney: UNSW Press.

- 2003b. Diglossia in Indonesian. Bijdragen tot de Taal-, Land- en Volkenkunde 159:519-549.

- 2006. Colloquial Jakarta Indonesian. Canberra: Pacific Linguistisc (581).

Steinhauer, Hein. 1994. The Indonesian language situation and linguistics; Prospects and possibilities. Bijdragen tot de Taal-, Land- en Volkenkunde 150: 755-784.

Syahdan (2000), Code-switching in the Speech of Elite Sasaks. In Peter Austin (ed), Working Papers in Sasak 2, 99-109. Melbourne, University of Melbourne, Department of Linguistics.

Voorhoeve, C.L. 1994. 'Contact-induced change in the non-Austronesian languages in the north Moluccas, Indonesia'. In Tom Dutton and Darrell Tryon (eds)

Language Conatct and Language Change in the Austronesian World, 649-674. Berlin/New York: Mouton de Gruyter.

Wallace, Alfred Russel. 1869. The Malay Archipelago London: Macmillan (reprinted by Periplus (HK) Ltd., paperback edition 2000).

Wolff, J.U. and S. Poedjosoedarmo. 1982. Communicative Codes in Central Java. Ithaca NY: Cornell University Press.

Wolters, O.W. 1967. Early Indonesian Commerce: A Study of the Origins of Srivijaya. New York: Cornell University Press.

Wurm, Stephen. 1975. 'Papuan languages and the New Guinea linguistic scene'. In S.Wurm (ed.) New Guinea Languages and Language Study Vol 1. Canberra: Pacific Linguistics (C-38). 
F i g u r 4

Percentage change in number of first langauge speakers, 1980 - 1990

Comparison of all speakers with age group $5-9$

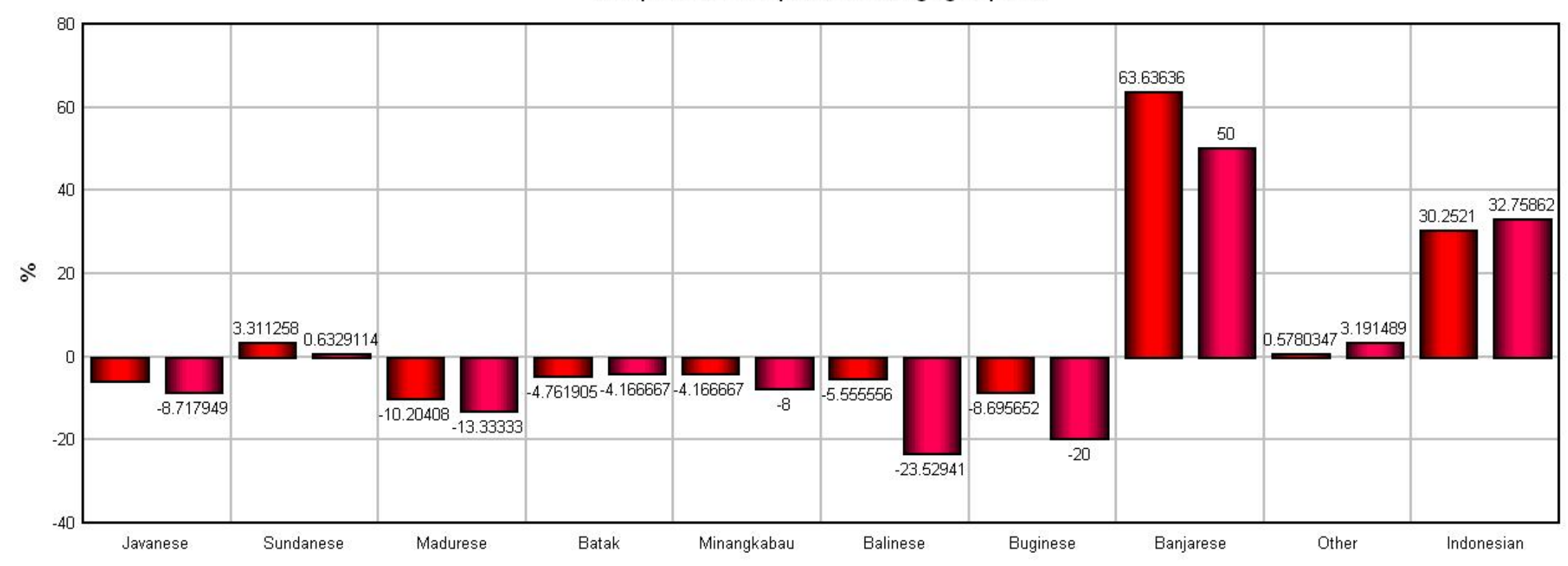

